\title{
Analysis of Students' Misconceptions on Solving Algebraic Contextual Problem
}

\author{
Faoza Saaroh ${ }^{1 *}$, Tian Abdul Aziz ${ }^{1}$, Dwi Antari Wijayanti ${ }^{1}$ \\ ${ }^{1}$ Universitas Negeri Jakarta, Jakarta
}

\begin{abstract}
Students misconceptions in solving contextual algebraic problems is still often found in this educational world. This study aims to describe the forms of student's misconceptions in solving algebraic contextual problems and explain the causes of these misconceptions. The approach in this research is a qualitative approach, that is library research where the data used are secondary data. This research uses literature review data collection techniques. The number of articles used as data sources is 19 articles related to topics in research with algebraic contextual items taken from 5 articles to be displayed in the results section of the study. Data analysis used descriptive analysis method by describing the intentions and comparing several research articles. The results showed several forms related to nonsystematic errors, namely concept errors or students' misconceptions in solving algebraic contextual problems, namely the occurrence of misconceptions within the scope of algebraic arithmetic operations, understanding the meaning of variables, simplifying, or operating algebraic expressions, and interpreting contextual problems into algebraic mathematical form. The misconception occurs in students with low and moderate mathematical abilities where the cause of this phenomenon is due to the occurrence of errors in the learning process by educators in which students are less accustomed to solving contextual problems or open-ended questions. Therefore, it is hoped that educators can determine the learning model appropriately in fixing the problem of contextual algebraic misconceptions and further researchers can find new learning models that affect this problem.
\end{abstract}

\section{ABSTRAK}

Miskonsepsi siswa dalam menyelesaikan masalah kontekstual aljabar masih sering ditemukan di dunia pendidikan ini. Penelitian ini bertujuan untuk mendeskripsikan bentuk miskonsepsi siswa dalam menyelesaikan masalah kontekstual aljabar serta menjelaskan penyebab dari miskonsepsi tersebut. Pendekatan dalam penelitian ini adalah pendekatan kualitatif, yakni library research di mana data yang digunakan adalah data sekunder. Penelitian ini menggunakan teknik pengumpulan data kajian pustaka. Jumlah artikel yang digunakan sebagai sumber data yaitu sebanyak 19 artikel terkait topik pada penelitian dengan butir soal kontekstual aljabar diambil dari 5 artikel untuk ditampilkan pada bagian hasil penelitian. Analisis data menggunakan metode deskriptif analisis dengan memaparkan maksud dan mengkomparasikan beberapa artikel penelitian. Hasil penelitian menunjukkan beberapa bentuk terkait kesalahan tidak sistematik, yakni kesalahan konsep atau miskonsepsi siswa dalam menyelesaikan masalah kontekstual aljabar yaitu terjadinya miskonsepsi dalam lingkup operasi aritmatika aljabar, pemahaman makna variabel, penyederhanaan ataupun pengoperasian ekspresi aljabar, serta interpretasi masalah kontekstual ke dalam bentuk matematis aljabar. Miskonsepsi ini terjadi pada peserta didik dengan kemampuan bermatematika yang rendah dan sedang serta penyebabnya yaitu karena terdapat kekeliruan proses pembelajaran oleh pendidik dimana peserta didik menjadi kurang terbiasa dalam menyelesaikan masalah kontekstual ataupun soal-soal yang bersifat open ended. Oleh karena itu, diharapkan pendidik dapat menentukan model pembelajaran secara tepat dalam memperbaiki masalah miskonsepsi aljabar konteksual serta peneliti selanjutnya dapat menemukan model pembelajaran baru yang berpengaruh pada masalah ini.
CONTACT

FaozaSaaroh_1301617070@mhs.unj.ac.id

KEYWORDS

Misconceptions, Algebra, Contextual Problem

Received: 28/02/2021

Revised: 25/03/2021

Accepted: 30/03/2021

Online: $25 / 04 / 2021$

Published: 30/04/2021

Risenologi is licenced under a Creative Commons Attribution 4.0 International Public Licence (CC-BY 4.0)

\section{INTRODUCTION}

Kurikulum 2013 yang diterapkan di Indonesia bukan hanya bertujuan untuk memperbarui suatu sistem pendidikan seiring berputarnya waktu. Namun, makna dari kurikulum tersebut tak lain adalah sebagai upaya yang dilakukan oleh pemerintah Indonesia dalam menyetarakan kualitas pendidikan menuju tingkat Internasional, dalam artian membentuk kualitas para siswa yang dapat mahir dalam menyelesaikan permasalahan kontekstual. Nyatanya, para siswa Indonesia masih mengalami suatu fenomena dalam pembelajaran matematika kontekstual khususnya pada materi Aljabar, yakni miskonsepsi (Jupri dkk., 2014). Fenomena ini merupakan masalah yang 
sering sekali ditemui dalam dunia pendidikan mulai dari siswa yang baru saja memulai materi aljabar, sampai kepada siswa yang sebenarnya telah melalui materi aljabar pada tingkat sebelumnya. Padahal materi matematika aljabar dapat dikatakan sebagai materi yang paling penting karena merupakan dasar dari berbagai materi matematika lanjutan dan bahkan pada materi pelajaran eksakta lainnya.

Leinhardt (1990, dalam Herutomo dan Saputro, 2014) mendefinisikan miskonsepsi matematika sebagai kesalahan pemahaman dalam pengetahuan siswa secara berulang dan tersurat dalam bermatematika. Terjadinya miskonsepsi pada siswa ketika menyelesaikan masalah kontekstual aljabar ditandai dengan kesalahan-kesalahan yang dilakukan oleh siswa tersebut selama proses penyelesaian masalah (Ambarwati dkk., 2018). Wati dan Murtiyasa (2016) memaparkan hasil penelitiannya terkait kesalahan siswa dalam menyelesaikan masalah kontekstual aljabar PISA (Change and Relationship), yakni didapat 4 jenis kesalahan dengan besar presentase untuk setiap jenis kesalahan yaitu kesalahan pemahaman (miskonsepsi) 55,50\%, kesalahan transformasi 27,75\%, kesalahan keterampilan proses 6,28\% dan kesalahan encoding 10,47\%. Penelitian tersebut menyatakan bahwa kesalahan konsep matematis memiliki persentase yang paling tinggi dibandingkan dengan kesalahan lainnya sehingga penelitian ini akan membahas hal penting tersebut. Sebagaimana yang Herutomo (2017) jelaskan, walaupun aljabar merupakan bagian dari ruang lingkup kurikulum matematika secara tersendiri, namun konsep aljabar pada dasarnya selalu tertanam dalam ruang lingkup matematika lainnya, seperti geometri, statistika, aritmatika, dan lain sebagainya.

Kesalahan dan miskonsepsi yang terjadi pada siswa ketika menyelesaikan suatu permasalahan matematika merupakan hal yang berhubungan namun sebenarnya berbeda. French (2002, dalam Ramadhani dkk., 2016) memaparkan bahwa miskonsepsi merupakan indikator yang bernilai bagi pemahaman siswa yang dapat memberikan informasi penting kepada guru agar dapat membangun serta mendiskusikan ide dan merancang tugas kelas dalam pembelajaran. Menurut McDonald (2010, dalam Taqiyuddin dkk., 2017) miskonsepsi merupakan pemahaman yang salah terhadap suatu konsep. Selanjutnya Brown (2013, dalam Silvia dkk., 2019) menyatakan tentang miskonsepsi sebagai suatu pandangan yang naif dan mendefinisikannya sebagai suatu gagasan yang tidak sesuai dengan pengertian ilmiah yang sekarang diterima. Menurut Salamah (2012, dalam Aini dan Siswono, 2014), aljabar merupakan salah satu cabang matematika yang berhubungan dengan variabel (simbol-simbol) dan persamaan, misalnya persamaan kuadrat dan persamaan pangkat tiga. Dari pendefinisian tersebut, kunci utama dalam konsep aljabar adalah variabel-variabel yang digunakan ketika menyelesaikan suatu permasalahan. Melanjutkan pernyataan tersebut, Herutomo (2017) mengemukakan pendapatnya bahwa aljabar merupakan cabang matematika yang paling rentan akan kesalahan pemahaman (miskonsepsi). Hal itu karena dominannya suatu pemahaman yang dinilai abstrak pada konsep aljabar. Berdasarkan pemaparan berbagai ahli, miskonsepsi aljabar merupakan kesalaham pemahaman atau konsep atau suatu ide abstrak yang terjadi pada individu tertentu (dalam hal ini yaitu siswa) terkait pada pemahamannya terhadap cabang ilmu matematika aljabar.

Penelitian terkait fenomena miskonsepsi aljabar secara tersendiri memang masih jarang dilakukan. Beberapa penelitian secara bersamaan membahas analisis kesalahan pada materi aljabar secara prosedural dan secara konseptual (miskonsepsi) sehingga penelitian dirasa kurang memiliki fokus tertenu yang lebih khusus dalam menghadapi suatu fenomena tertentu, misalnya saja pada permasalahan yang terjadi di SMP Negeri 33 Semarang. Siswa melakukan kesalahan dalam menyelesaikan soal-soal terkait materi aljabar karena kurangnya pemahaman prosedural dan konseptual dalam materi aljabar (Herutomo dan Saputro, 2014). Oleh karena itu, penelitian ini akan fokus terhadap miskonsepsi aljabar.

Salah satu penyebab dari terjadinya miskonsepsi siswa yaitu karena sulitnya siswa dalam menerima suatu konsep matematika. Terdapat beberapa kesulitan konseptual dalam cabang matematika aljabar awal (Jupri dkk., 2014).

a. Menerapkan operasi aritmatika, yakni melakukan penjumlahan, pengurangan, perkalian, dan pembagian pada beberapa bilangan maupun variabel.

b. Memahami gagasan variabel, yakni variabel sebagai suatu wadah kosong yang dapat menyimpan serta mengambil kembali nilai numerik, variabel sebagai sesuatu yang belum diketahui, variabel sebagai kuantitas yang bervariasi, variabel sebagai generalisasi pola yang melambangkan kesetaraan.

c. Memahami arti yang berbeda dari tanda sama dengan, yakni sebagai suatu tanda ekuivelensi, misalnya $2+7=7+2 ; 2+7=1+8$ dan sebagainya.

d. Memahami ekspresi aljabar, yakni membedakan antara bahasa sehari-hari dengan bahasa aljabar, menduga suatu bilangan sebagai solusi bentuk aljabar, mengoperasikan sebuah bentuk aljabar dengan suatu bilangan sehingga meghasilkan sebuah bentuk aljabar, dan mengabaikan simbol pertidaksamaan aljabar dalam menyelesaikan bentuk aljabar. 
e. Menerjemahkan masalah ke bentuk matematis, yakni masalah matematisasi horizontal yang terfokus pada perubahan masalah fenomena nyata ke simbol matematis dan sebaliknya, serta matematisasi vertikal yang berkaitan dengan proses reorganisasi dalam sistem matematisnya itu sendiri.

Masalah kontekstual aljabar merupakan suatu masalah nyata berdasarkan pada hal-hal terkait kehidupan sehari-hari yang disajikan dalam bentuk soal cerita (Putri, Sumardani, Rahayu, \& Hajizah, 2020) dan berhubungan dengan simbol (biasanya berupa huruf), variabel, dan persamaan dengan cara penyelesaiannya tidak langsung mempunyai aturan atau algoritma atau pola tertentu yang akan segera dapat digunakan untuk menentukan solusinya (Aini dan Siswono, 2014). Oleh karena itu, soal aljabar yang bersifat kontekstual dapat dikatakan sebagai suatu soal yang tidak rutin mengingat prosedur penyelesaiannya yang tidak sederhana.

PISA (Programme for International Student Assessment) merupakan bentuk penilaian berstandar Internasional yang dikembangkan bersama negara-negara pesert meliputi domain matematika (mereproduksi pengetahuan tertentu, menerapkan pengetahuan dalam situasi baru, problem solving, dan financial literacy), membaca, dan ilmu pengetahuan (Salsabila, Rahayu, Kharis, \& Putri, 2019). Johar (2012) menjelaskan bahwa konten Change and Relationship pada PISA merupakan salah satu contoh masalah kontekstual matematika aljabar. Ariyadi Wijaya dkk. (2014, dalam Wildani, 2016) memaparkan penelitiannya terkait identifikasi kesulitan siswa di Indonesia dalam memecahkan soal matematika berbasis PISA serta menyimpulkan bahwa siswa di Indonesia kesulitan dalam memahami tugas berbasis konteks dan mengubahnya menjadi masalah matematika. Faktor penyebab dari kekeliruan yang dilakukan oleh siswa ketika menyelesaikan masalah kontekstual memang perlu dikaji lebih dalam lagi.

Pemahaman siswa dalam menyelesaikan masalah kontekstual aljabar pada PISA merupakan kemampuan yang dimiliki oleh siswa dalam menggunakan suatu situasi, fakta, konsep, prinsip, menghubungkan informasi baru dengan pengetahuan yang dimiliki sebelumnya, serta dapat menarik kesimpulan dari tabel, data, dan grafik untuk memperoleh jawaban dari soal atau pertanyaan aljabar pada PISA yang berhubungan dengan simbol, variabel, dan persamaan dengan menggunakan konsep, pengetahuan, rumus, dan perhitungan yang telah dimiliki oleh siswa (Aini dan Siswono, 2014).

Beberapa penelitian memaparkan terkait miskonsepsi yang dialami oleh siswa terkait ruang lingkup aljabar. Byrd dkk. (2015) melakukan suatu penelitian dengan menggunakan item soal aljabar yang masih dominan menggunakan soal-soal rutin (walaupun terdapat beberapa yang menggunakan soal non rutin) untuk diuji coba kepada siswa karena memang tujuannya adalah untuk memfokuskan pada miskonsepsi terhadap tanda sama dengan. Begitu juga dengan penelitian yang dilakukan oleh Lucariello dkk. (2014) yang secara keseluruhan menggunakan instrumen soal yang bersifat rutin, yakni langsung pada soal-soal persamaan aljabar, karena mungkin tujuannya yang hanya melihat pada miskonsepsi variabel. Berkaitan akan hal tersebut, penelitian yang dilakukan yaitu fokus dengan menggunakan masalah aljabar yang bersifat kontekstual atau non rutin.

Berpikir aljabar merupakan pola bepikir yang dinilai kompleks karena mengingat abstraknya konsep aljabar itu sendiri. Untuk menggali munculnya berpikir aljabar pada siswa, salah satu hal yang dapat dilakukan yaitu dengan diberikannya suatu permasalahan kontekstual yang melibatkan konsep aljabar, kemudian siswa diminta untuk dapat memecahkan masalah tersebut, karena konsep aljabar itu sendiri akan lebih mudah dipahami oleh siswa jika dikaitkan dengan masalah nyata (Yusrina dan Masriyah, 2019). Selanjutnya pada suatu hasil penelitian Lingga dan Sari (2013, dalam Yusrina dan Masriyah, 2019), kemampuan dalam memecahkan masalah matematika kontekstual dipengaruhi oleh kemampuan berpikir aljabar, yakni siswa yang memiliki kemampuan berpikir aljabar dengan baik cenderung lebih mahir dalam memecahkan masalah matematika.

Untuk mengetahui karakteristik dari siswa berdasarkan kemampuannya dalam bermatematika terkait miskonsepsi pada penyelesaian masalah kontekstual aljabar, Yusrina dan Masriyah (2019) menganalisis hasil penelitiannya dengan mengacu pada indikator berfikir aljabar yaitu generalisasi (mengidentifikasi hubungan antar objek dan menemukan polanya), abstraksi (menggunakan representasi simbol variabel sebagai sesuatu yang belum diketahui nilainya berdasarkan generalisasi), berpikir dinamis (memecahkan masalah dengan berbagai cara), pemodelan (merepresentasikan masalah menjadi model matematika), berpikir analitis (menyelesaikan masalah menggunakan persamaan untuk menentukan nilai variabel), dan organisasi (memilih dan menyusun data dengan tabel, atau gambar, atau diagram, atau kata-kata, yang dapat menggambarkan masalah dan hubungan antara kondisi masalah secara keseluruhan).

Anggo (2011, dalam Yusrina dan Masriyah, 2019) mengemukakan pendapat bahwasannya konteks yang digunakan pada pembelajaran matematika berdasarkan pemikiran yang dibangun dari situasi realistik (situasi nyata atau kontekstual) yang sudah dikenal baik oleh siswa dapat menjadikan konsep abstrak seperti pada aljabar dapat dipahaminya. Berdasarkan Kurikulum 2013 Permendikbud No. 21 Tahun 2016, siswa Indonesia memang dituntut akan kemampuannya dalam memecahkan masalah kontekstual. Selanjutnya Puspitarini dan Masriyah (2017) berpendapat tentang tuntutan tersebut dalam pembelajaran materi aljabar bahwa upaya untuk mewujudkannya yaitu dengan memberikan masalah kontekstual aljabar dalam kegiatan pembelajaran kepada 
siswa Indonesia. Walaupun pada kenyataannya masih banyak siswa Indonesia yang mengalami miskonsepsi terkait masalah kontekstual aljabar.

Tujuan dari penelitian ini adalah untuk mendeskripsikan berbagai bentuk miskonsepsi siswa dalam menyelesaikan masalah kontekstual aljabar serta menjelaskan penyebab dari miskonsepsi tersebut. Studi literatur ini terbatas pada deskripsi mengenai miskonsepsi apa saja yang siswa alami selama mereka melakukan penyelesaian masalah kontekstual aljabar dan penjelasan tentang faktor penyebab terjadinya miskonsepsi tersebut.

\section{METHODS}

Pendekatan dalam penelitian ini menggunakan pendekatan kualitatif. Moleong (2011, dalam Herutomo dan Saputro, 2014) menyatakan bahwa pendekatan kualitatif bermaksud untuk memahami fenomena yang dialami oleh subjek penelitian secara holistik dan dengan cara pendeskripsian menggunakan kata-kata dan bahasa pada konteks yang ilmiah dengan memanfaatkan berbagai metode ilmiah. Adapun jenis penelitian ini adalah penelitian kepustakaan atau library research dengan data yang digunakan adalah data sekunder, yakni data yang diambil dari penelitian-penelitian lain sebelumnya yang menggunakan data primer. Library research merupakan jenis penelitian yang memanfaatkan sumber-sumber kepustakaan untuk memperoleh data penelitian.

Teknik pengumpulan data yang digunakan dalam penelitian ini adalah studi/kajian pustaka, yakni pengumpulan data dengan menelaah berbagai literatur terkait topik penelitian. Berbagai literatur yang dimaksud yaitu berupa artikel dalam jurnal yang dijadikan referensi pada penelitian ini dan sudah terakreditasi baik secara Nasional ataupun secara Internasional dengan rentang waktu penerbitan jurnal yaitu 10 tahun terakhir. Jumlah artikel yang digunakan sebagai sumber data yaitu sebanyak 19 artikel dengan butir soal-soal kontekstual aljabar diambil dari 5 artikel terkait untuk ditampilkan pada bagian hasil penelitian. Adapun cara pemilihan 19 artikel tersebut yaitu dengan memperhatikan variabel-variabel yang digunakan dalam penelitian terkait miskonsepsi aljabar dan masalah kontekstual aljabar, kemudian dipilih kembali 5 artikel yang membahas tentang miskonsepsi pada masalah kontekstual aljabar untuk dideskripsikan pada hasil penelitian tersebut. Metode pengkajian pada penelitian ini adalah studi literatur yang tidak mengharuskan peneliti untuk turun ke lapangan dan bertemu dengan responden.

Dalam menganalisis data, metode deskriptif analisis digunakan dengan menjelaskan dan memaparkan maksud dari beberapa artikel penelitian yang dijadikan sumber tersebut. Dalam analisis data juga sedikit dilakukan komparasi beberapa artikel terkait yang sekiranya agak berbeda dari beberapa sumber artikel lainnya. Adapun penelitian ini akan menguraikan bentuk-bentuk miskonsepsi siswa dalam menyelesaikan masalah kontekstual aljabar serta penyebab dari terjadinya miskonsepsi tersebut.

\section{RESULTS}

Penelitian kepustakaan ini bertujuan untuk menganalisis miskonsepsi yang terjadi pada peserta didik dalam menyelesaikan masalah kontekstual aljabar. Dari kegiatan pengumpulan data sekunder yang dilakukan berdasarkan prosedur dalam metodologi penelitian, didapat hasil penelitian terkait miskonsepsi siswa SMP dalam menyelesaikan masalah kontekstual aljabar pada tabel sebagai berikut.

Tabel 1. Hasil Penelitian Herutomo dan Saputro (2014).

\begin{tabular}{|c|c|c|}
\hline No & Butir Soal Kontekstual Aljabar & Deskripsi Jawaban Siswa \\
\hline \multirow[t]{3}{*}{1} & \multirow{3}{*}{$\begin{array}{c}\text { Harga satu buah pensil adalah p rupiah dan } \\
\text { harga sebuah buku tulis adalah b rupiah. } \\
\text { Ana membeli tiga buah pensil dan lima } \\
\text { buah buku tulis. Hitunglah berapa rupiah } \\
\text { dari total harga yang harus dibayar oleh } \\
\text { Ana? }\end{array}$} & $\begin{array}{l}\text { Sebanyak } 25 \% \text { siswa dengan kemampuan bermatematika yang } \\
\text { sedang menjawab soal dengan langsung memisalkan harga dari } \\
\text { pensil dan buku untuk menemukan solusi dari masalah kontekstual } \\
\text { tersebut tanpa memperhatikan variabel p dan b pada soal. } \\
\mathrm{p}=\text { pensil dan b = buku } \\
\text { Harga } 3 \text { pensil }=3 \times \text { Rp. } 2.000=\text { Rp. } 6.000 \\
\text { Harga } 5 \text { buku }=5 \times \text { Rp. } 3.000=\text { Rp. } 15.000 \\
3 \text { pensil }+5 \text { buku }=\text { Rp. } 21.000\end{array}$ \\
\hline & & $\begin{array}{l}\text { Sebanyak } 23,2 \% \text { siswa dengan kemampuan yang sama melakukan } \\
\text { kesalahan dalam mengoperasikan bentuk aljabar. } \\
3 \mathrm{p}+5 \mathrm{~b}=8 \mathrm{pb}\end{array}$ \\
\hline & & $\begin{array}{l}\text { Sebanyak } 5 \% \text { siswa dengan kemampuan matematis yang rendah } \\
\text { melakukan kesalahan dalam interpretasi masalah kontekstual ke } \\
\text { bentuk aljabar untuk ditemukan solusinya. } \\
\text { Total harga }=3 \text { p.5b }\end{array}$ \\
\hline
\end{tabular}


Fina akan membeli buah jeruk dan apel. belas buah. Berapa banyak masing-masing buah yang mungkin dibeli oleh Fina?
2 Dia merencanakan membeli sebanyak lima

Sebanyak 5\% siswa berkemampuan matematis rendah dan 28, 3\% siswa berkemampuan matematis sedang melakukan penyelesaian masalah dengan langsung menggunakan bilangan tertentu.

Misalkan apel $=\mathrm{A}$ dan jeruk $=\mathrm{B}$,

$\mathrm{A}+\mathrm{B}=15, \mathrm{~B}=15-8=7 \mathbf{( 5 \% )}$;

7 apel dan 8 jeruk, 5 apel dan 10 jeruk, ..., 14 apel dan 1 jeruk $(28,3 \%)$

banyak buah yang dibeli= $15: 2=7,5(\mathbf{5 \%}) ; j+a=15,9+6=15$, $8+7=15(\mathbf{5 \%})$

Sebanyak $13 \%$ siswa berkemampuan sedang menyelesaikan masalah dengan menggunakan persamaan bentuk aljabar yang tidak tepat.

$j+a=15$ dan $8 j+7 a=15(5 \%) ; j=15 a$ dan $a=15 j$

Diketahui ada empat kali banyak siswa kelas VIIIB dari banyak guru yang mengajar di kelas tersebut pada suatu 3 sekolah. S menyatakan banyak siswa, sedangkan $\mathrm{G}$ menyatakan banyak guru di sekolah itu. Buatlah hubungan antara S dan $\mathrm{G}$ dalam bentuk aljabar.

Diketahui umur Budi lebih muda dari Amir, selisih umur Amir dan Budi saat ini adalah dua belas tahun. Empat tahun yang akan datang, umur Amir adalah dua kali umur Budi. Berapakah umur mereka sekarang?

$\mathrm{A}-\mathrm{B}=12, \mathrm{~A}+4=2+(\mathrm{B}+4)(\mathbf{1 4}, \mathbf{3} \%)$
Sebanyak 26,7\% iswa dengan kemampuan matematis yang sedang melakukan kesalahan dalam menginterpretasikan masalah ke dalam bentuk aljabar menggunakan variabel yang ditentukan pada soal, yakni dengan jawaban $4 S=G$

Sebanyak 34, $2 \%$ siswa berkemampuan matematis yang sedang menyelesaikan masalah tanpa menggunakan persamaan aljabar yakni hanya secara verbal atau pendeskripsian dengan kata-kata.

Sebanyak $22.8 \%$ siswa dengan kemampuan matematis yang rendah melakukan penyelesaian tanpa cara, yakni didapatkan hasil:

Umur Amir $=20$ tahun

Umur Budi $=8$ tahun

Siswa berkemampuan matematis yang sedang menunjukkan kekeliruan dalam merepresentasikan masalah ke dalam bentuk persamaan aljabar.

$\mathrm{A}-\mathrm{B}=12$ dan $\mathrm{J}=2 \mathrm{~B}+4 \mathbf{( 2 0 \% )}$

Sebanyak $8,5 \%$ siswa berkemampuan matematis yang sedang melakukan penyederhanaan bentuk aljabar dengan langsung memisalkan variabel menggunakan bilangan.

$\mathrm{A}>\mathrm{B}, \mathrm{A}-\mathrm{B}=12 \rightarrow 20-8=12$ Umur Amir $=20+4=24$

Umur Budi $=8+4=12$

Tabel 2. Hasil Penelitian Ambarwati dkk. (2018).

Butir Soal Kontekstual Aljabar

Di bawah ini adalah 3 lemari dengan tinggi yang berbeda serta tersusun dari dua bentuk yaitu persegi dan persegi panjang. Berapa tinggi lemari yang paling pendek?

\section{Deskripsi Jawaban Siswa}

Siswa berkemampuan matematis yang tinggi hanya melakukan kesalahan secara sistematik, yakni keliru dalam melakukan operasi pengurangan suatu bilangan.

Siswa dengan kemampuan matematis yang sedang melakukan kesalahan dalam operasi bentuk aljabar terhadap suatu variabel yang terdapat pada persamaan aljabar yang telah dibentuknya.

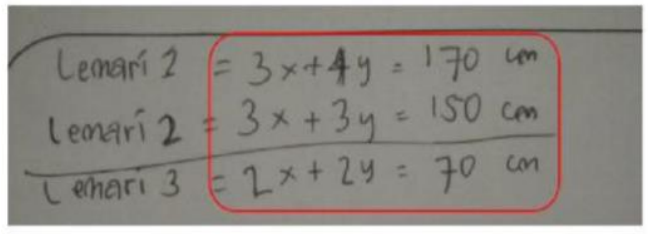




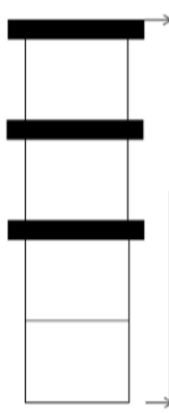

Lemari 1

Keterangan:

Panjang persegi panjang $=$ Arsiran hitam

Panjang persegi $=$ Tidak diarsir

(soal PISA Change and Relationship yang sudah dimodifikasi)
Siswa dengan kemampuan matematis yang rendah melakukan penyelesaian tanpa menuliskan caranya. Selain itu, siswa melakukan kesalahan dalam melakukan operasi bentuk aljabar terhadap suatu variabel tertentu.

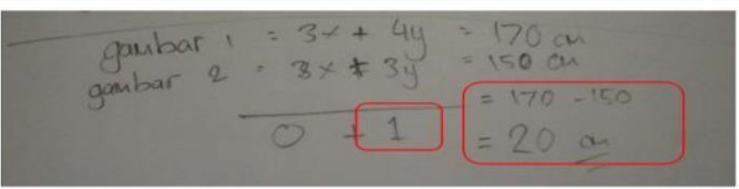

Tabel 3. Hasil Penelitian Zain dkk. (2016).

\section{Butir Soal Kontekstual Aljabar}

Pak Ali memiliki kebun manga dengan bentuk persegi panjang. Lebar kebun tersebut $(2 x+3) \mathrm{m}$

dan keliling kebun yaitu $150 \mathrm{~m}$. Jika panjang kebun mangga pak Ali adalah dua kali dari lebar kebun tersebut, maka hitunglah panjang dan lebar kebun mangga pak Ali yang sebenarnya?

\section{Deskripsi Jawaban Siswa}

Siswa dengan kemampuan matematis yang tinggi dapat menyelesaikan masalah kontekstual aljabar dengan baik tanpa adanya kesalahan yang ditunjukkan baik dalam proses menerjemahkan ke dalam bentuk persamaan aljabar, menyederhanakan persamaan aljabar dengan pengoperasian variebel yang ada hingga menemukan solusi dari masalah tersebut.
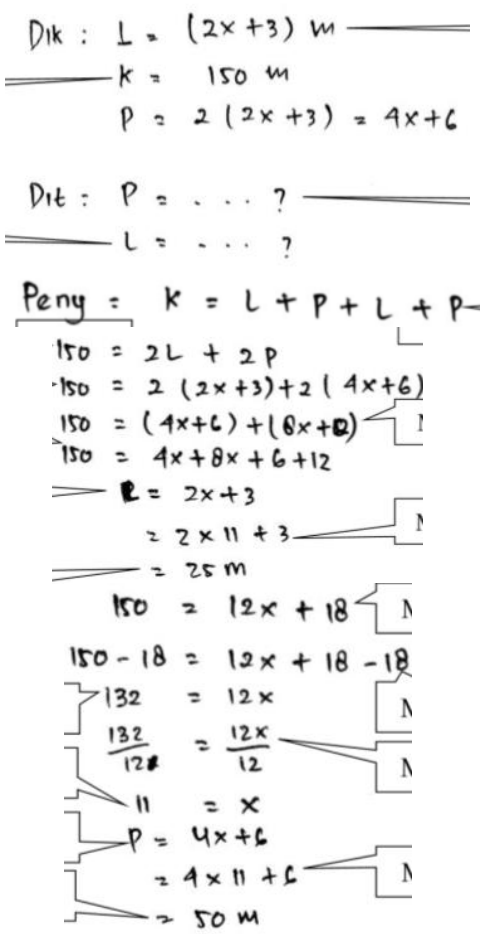

Siswa dengan kemampuan matematis yang sedang mengalami kesalahan konsep dalam pengoperasian bentuk aljabar antara variabel dan bilangan. Namun, ia dapat memperbaiki kesalahan tersebut

$$
\begin{aligned}
\text { Dik }=\text { Lebar kebun } & =(2 x+3) \mathrm{m} \\
\text { Keliling } & =150 \mathrm{~m} \\
\text { Panjang kebun } & =2(2 x+3)
\end{aligned}
$$

Dit = Panbang dan lebar kebun yang sesungguhnya 


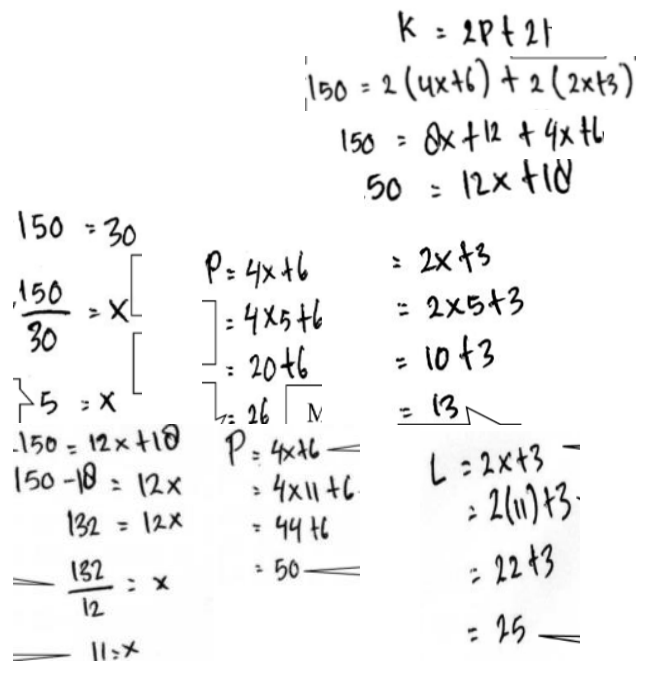

Siswa dengan kemampuan matematis yang rendah melakukan kesalahan konsep dalam menerjemahkan masalah kontekstual aljabar ke dalam bentuk matematis aljabar sehingga pekerjaannya tidak dapat diselesaikan lebih lanjut.

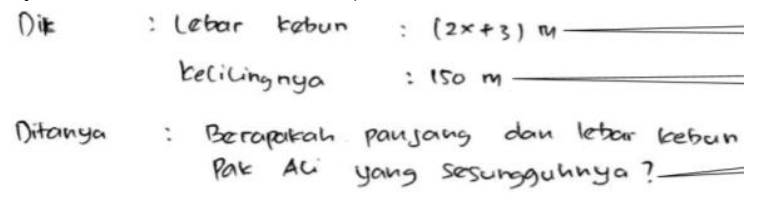

Tabel 4. Hasil Penelitian Wati dan Murtiyasa (2016).

\begin{tabular}{|c|c|c|}
\hline No & Butir Soal Kontekstual Aljabar & Deskripsi Jawaban Siswa \\
\hline \multirow{3}{*}{1} & \multirow{2}{*}{$\begin{array}{c}\text { Sebuah kedai pizza menyajikan } 2 \text { pilihan pizza } \\
\text { dengan ketebalan yang sama namun berbeda } \\
\text { ukuran. Pizza kecil berdiameter } 30 \mathrm{~cm} \text { dengan } \\
\text { harga } 30 \text { zed. Pizza besar berdiameter } 40 \mathrm{~cm} \\
\text { dengan harga } 40 \text { zed. Pizza manakah yang lebih } \\
\text { murah? Jelaskan alasannya! }\end{array}$} & $\begin{array}{l}\text { Siswa dengan kemampuan matematis yang lemah dalam } \\
\text { menyelesaikan masalah kontekstual aljabar PISA tidak } \\
\text { mampu menerjemahkan masalah ke dalam bentuk aljabar } \\
\text { yang dapat diselesaikan lebih lanjut. }\end{array}$ \\
\hline & & 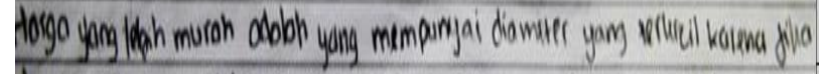 \\
\hline & $\begin{array}{l}\text { Catatan: Asosiasikan bilangan satuan harga dalam } \\
\text { zed pada soal dengan bilangan satuan harga rupiah. }\end{array}$ & 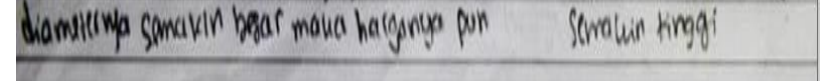 \\
\hline \multirow[t]{2}{*}{2} & \multirow{2}{*}{$\begin{array}{l}\text { Ban sepeda Peter memiliki keliling } 96 \mathrm{~cm} \text {. } \\
\text { Perbandingan banyaknya putaran ban dan ketiga } \\
\text { gir sepeda (kecil, sedang, dan besar) yaitu sebagai } \\
\text { berikut (gir : ban). } \\
\text { Kecil } 3: 1 \quad \text { Sedang 6:5 Besar } 1: 2 \\
\begin{array}{l}\text { Berapa kali putaran gir sedang sepeda Peter yang } \\
\text { dibutuhkan untuk menempuh jarak } 960 \mathrm{~m} !\end{array}\end{array}$} & $\begin{array}{l}\text { Siswa dengan kemampuan matematis yang lemah dalam } \\
\text { menyelesaikan masalah kontekstual aljabar PISA tidak } \\
\text { mampu mengidentifikasi masalah ke dalam konsep aljabar } \\
\text { menggunakan variabel. }\end{array}$ \\
\hline & & $6: 5 \quad 5 \times 96: 480: 6: 80$ \\
\hline \multirow{8}{*}{3} & \multirow{8}{*}{$\begin{array}{l}\text { Terdapat } 3 \text { tower dengan tinggi berbeda dan } \\
\text { tersusun dari } 2 \text { bentuk yaitu segi enam dan persegi } \\
\text { panjang. Berapa tinggi tower terpendek? }\end{array}$} & $\begin{array}{l}\text { Siswa dengan kemampuan matematis yang sedang } \\
\text { melakukan kesalahan konsep dalam menerjemahkan masalah } \\
\text { kontekstual aljabar PISA ke dalam persamaan aljabar untuk } \\
\text { didapat solusi dari masalah tersebut. }\end{array}$ \\
\hline & & \multirow{2}{*}{$\begin{array}{l}\text { Diket: } \operatorname{long}_{\text {won }} A=21 \mathrm{~m} \\
\log _{0} B=B \mathrm{~m}\end{array}$} \\
\hline & & \\
\hline & & Ditamo : tingi bangun C...m? \\
\hline & & $\begin{array}{rl}\text { Junat: } 2 x+6 y=21 & 2 x+5(2)=18 \\
2 x+5 y=19 & 2 x+10=19\end{array}$ \\
\hline & & $y=2 \quad 2 x=19-10$ \\
\hline & & $2 x=9$ \\
\hline & & $x: 4.5 \mathrm{mp}$ \\
\hline
\end{tabular}

Tabel 5. Hasil Penelitian Jupri dkk. (2014). 


\begin{tabular}{cc}
\hline No & Butir Soal Kontekstual Aljabar \\
\hline & \\
& Sebuah kubus dengan panjang rusuk $(\mathrm{x}+2) \mathrm{cm}$ akan \\
dibuat. Jika rangka kubus tersebut akan dibuat dari \\
seutas kawat yang panjangnya tidak lebih dari $180 \mathrm{~cm}$, \\
tentukan batas-batas panjang kubus tersebut!
\end{tabular}
persegi-persegi kecil.

2
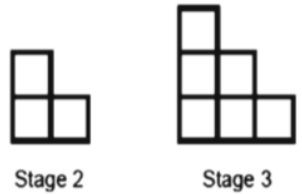

Kamu bisa lihat bahwa Robert menggunakan satu persegi untuk Tangga 1, tiga persegi untuk Tangga 2, dan enam persegi untuk Tangga 3. Berapa banyak persegi yang diperlukan Robert untuk membuat Tangga 4?

\section{Deskripsi Jawaban Siswa}

Siswa berkemampuan sedang mengalami kesalahan konsep dalam membentuk konsep aljabar dari masalah kontekstual. Siswa membuat suatu persamaan aljabar padahal perintah soal yaitu menggunakan pertidaksaamaan bentuk aljabar. Kemudian juga siswa mengalami miskonsepsi dalam mengoperasikan bentuk aljabar.

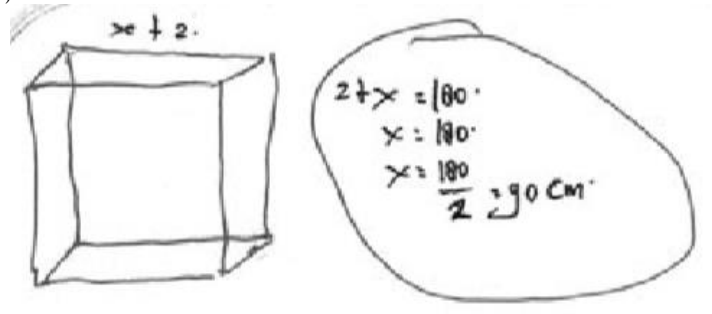

Siswa berkemampuan matematis yang sedang mengalami kesalahan konsep dalam menginterpretasikan masalah kontekstual aljabar dalam mendapatkan solusi. Siswa mengalami kesulitan dalam menemukan beda dari jumlah persegi untuk membentuk tiap tangga sehingga solusi yang diberikan adalah tidak tepat.

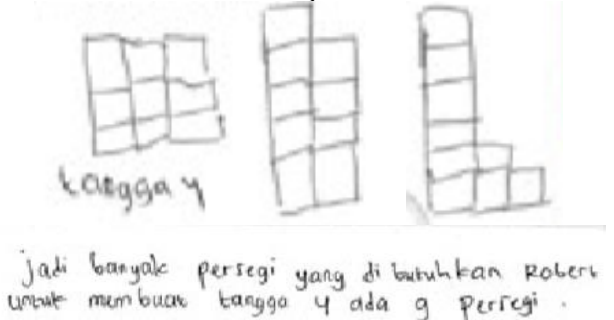

\section{DISCUSSIONS}

Dari kelima tabel pada hasil penelitian di atas, ditemukan beberapa hal penting terkait kesalahan tidak sistematik, yakni kesalahan konsep atau miskonsepsi siswa dalam menyelesaikan masalah kontekstual aljabar. Hal itu terdiri dari terjadinya miskonsepsi dalam lingkup pemahaman variabel, penyederhanaan ataupun pengoperasian persamaan bentuk aljabar, serta interpretasi masalah kontekstual ke dalam bentuk aljabar.

Siswa dengan kemampuan matematis yang tinggi cenderung berhasil dalam menyelesaikan masalah kontekstual aljabar sehingga miskonsepsi hanya terjadi pada siswa dengan kemampuan matematis yang sedang dan rendah (Yusrina dan Masriyah, 2019). Hal itu ditemukan pada hasil penelitian Zain dkk. (2016) yang telah dideskripsikan sebelumnya. Adapun hasil yang diperoleh dari beberapa penelitian sebelumnya terkait kesalahan konsep yang dilakukan oleh siswa dalam menyelesaikan masalah kontekstual aljabar dapat diklasifikasikan menurut Jupri dkk. (2014) ke dalam empat bentuk miskonsepsi aljabar sebagai berikut.

\section{Operasi Aritmatika Aljabar}

Miskonsepsi yang terjadi pada operasi bentuk aljabar ini yaitu berupa konjoining operasi penjumlahan dan perkalian yang ditunjukkan pada soal nomor 1 Tabel 1. ataupun pengurangan dan pembagian pada soal nomor 1 Tabel 5. dan soal pada Tabel 3.

Herutomo (2017) menjelaskan bahwasannya konjoining operasi terjadi akibat ketidakpercayaan diri siswa dalam menyelesaikan masalah kontekstual aljabar yang bersifat terbuka dengan solusi yang masih berbentuk ekspresi aljabar. Siswa merasa bahwa solusi tersebut masih belum lengkap, sehingga siswa memaksakan diri untuk menemukan suatu solusi aljabar yang tertutup dan paling sederhana dengan menerapkan konsep yang salah dalam melakukan operasi aritmatika aljabar, misalnya jika didapat hasil $\mathrm{p}+\mathrm{q}$ maka siswa melakukan operasi perkalian agar jawaban menjadi pq. Penyebab terjadinya miskonsepsi siswa pada operasi aritmatik ini juga disebabkan karena siswa menafsirkan operasi aljabar penjumlahan "+” dan pengurangan "_ merupakan suatu yang harus dioperasikan agar mendapat satu digit jawaban (Herutomo dan Saputro, 2014). Dari alasan siswa dalam melakukan miskonsepsi bentuk ini, maka dapat dikatakan bahwa siswa kurang terbiasa dalam 
menyelesaikan soal-soal kontekstual aljabar yang bersifat open-ended sehingga pendidik sekiranya harus dapat memberikan variasi soal-soal latihan kepada siswanya.

Miskonsepsi jenis ini dapat berkelanjutan pada pemahaman konsep tanda "=". Knuth dkk. (2008, dalam Herutomo, 2017) menjelaskan bahwa tanda sama dengan juga menunjukkan konsep kesetaraan (hubungan antara dua kuantitas) dan bukan hanya menunjukkan penanda hasil dari suatu operasi aritmatika.

\section{Variabel}

Terkait pemahaman mengenai beberapa gagasan tentang variabel, miskonsepsi jenis ini terdiri dari menganggap konstanta sebagai variabel dan menganggap variabel sebagai label (kurang memahami konsep variabel sebagai sesuatu yang belum diketahui nilainya), menganggap variabel hanya merepresentasikan nilai atau bilangan tertentu saja (bukan sebagai generalisasi anggota suatu himpunan bilangan), yang ditandai dengan aktivitas siswa mengganti variabel dengan nilai tertentu (Herutomo, 2017).

Dalam Tabel 1. pada soal nomor 1, 3, dan 4, siswa kurang memahami konsep variabel sebagai sesuatu yang belum diketahui nilainya. Hal itu ditandai dengan jawaban siswa yang langsung mengganti suatu variabel dengan bilangan tertentu dalam menyelesaikan masalah kontekstual aljabar yang diberikan. Variabel masih dianggap sebagai sesuatu yang berorientasikan pada operasi aritmatika pada suatu nilai tertentu. Penyebab dari terjadinya hal tersebut yaitu dikarenakan siswa hanya berfokus pada contoh-contoh soal yang bersifat rutin terkait masalah kontekstual aljabar. Selain itu juga terjadi kepasifan siswa dalam pemahaman konsep variabel, yakni siswa kesulitan dalam menghadapi masalah yang dinilai non rutin ini dengan mengalihkannya pada pemisalan variabel dengan suatu nilai yang nyata. Kesalahan siswa dalam memahami konsep variabel ini juga ditandai dengan siswa yang langsung menerjemahkan pernyataan soal dalam bahasa simbol tanpa melakukan proses perbandingan. Dalam artian siswa masih menganggap bahwa variabel merupakan simbol yang tidak memiliki makna berarti. Selanjutnya bahwa Clement (1982, dalam Herutomo dan Saputro, 2014) menjelaskan bahwa proses perbandingan tersebut merupakan proses penyesuaian kata-kata ke dalam konsep variabel yang dibentuk. Variabel bukan hanya representasi suatu objek, melainkan lebih pada kuantitasnya. Jika kekeliruan ini dibiarkan, maka akan terjadi kerancuan antara variabel dan label dimana sudah jelas bahwasannya variabel bukanlah sekadar label.

Pada Tabel 1. soal nomor 2, Herutomo dan Saputro (2014) mendapatkan responden siswa yang menganggap variabel bukan sebagai generalisasi suatu himpunan bilangan. Hal itu terjadi karena siswa masih berpaku dalam pemahaman bahwa variabel memiliki gagasan tentang sesuatu yang belum diketahui nilainya. Terkait soal nomor 2, siswa belum dapat memahami konsep variabel yang digunakan dalam penyelesaian masalah kontekstual tersebut, yakni merupakan himpunan bilangan cacah dikarenakan makna dari variabel pada soal itu adalah jumlah dari suatu benda.

\section{Ekspresi Aljabar}

Miskonsepsi bentuk ekspresi aljabar yang dimaksud dalam hal ini yaitu pada ekspresi persamaan aljabar serta pertidaksamaan aljabar baik dalam hal penyederhanaan ataupun pengoperasian ekspresi aljabar itu sendiri. Hal itu untuk mendapatkan solusi dari masalah kontekstual yang diberikan.

Pada Tabel 2., siswa dengan kemampuan matematis yang sedang dan rendah mengalami kesalahan konsep dalam menyederhanakan ekspresi persamaan aljabar dengan pengoperasian bentuk aljabar yang keliru. Hal ini terjadi karena dalam menyederhanakan bentuk aljabar, siswa cenderung mengubahnya menjadi suatu persamaan kemudian mencari penyelesaiannya. Kesalahan konsep dalam menyederhanakan suatu persamaan aljabar juga terlihat pada Tabel 1. yang ditunjukkan oleh jawaban siswa untuk soal nomor 2 dimana siswa gagal dalam memahami ekspresi persamaan menggunakan tanda "=" sebagai suatu yang representatif. Herutomo (2017) menjelaskan bahwa berbagai penelitian menyebutkan jikalau fenomena ini merupakan kegagalan dalam transisi aritmatika ke dalam bentuk aljabar dimana aritmatika merujuk pada sesuatu yang spesifik dan aljabar pada sesuatu yang general. Lebih lanjut mengenai dua level berfikir hierarki tersebut, Amerom (2003, dalam Herutomo, 2017) mengemukakan tentang berfikir aritmatika yang merupakan proses berfikir langsung dari sesuatu yang sudah diketahui menuju sesuatu yang belum diketahui sedangkan berfikir aljabar merupakan proses penalaran variabel dengan berfikir dari yang belum diketahui menggunakan sesuatu yang diketahui sehingga terbentuk suatu persamaan. Kekeliruan siswa dalam memahami konsep ini selanjutnya juga akan menghambat siswa dalam melakukan penyederhanaan ekspresi aljabar yang menuntut kegiatan pemfaktoran.

Untuk hasil penelitian pada Tabel 5. soal nomor 1 yang dipaparkan oleh Jupri dkk. (2014), jawaban siswa menunjukkan miskonsepsi dalam ekspresi aljabar yang ditandai dengan diabaikannya bahasa verbal pada soal yang bermakna suatu bentuk pertidaksamaan aljabar dalam penyelesaian masalah yang disajikan. Dalam hal ini juga siswa masih melakukan kekeliruan dalam konsep persamaan dan petidakamaan bentuk aljabar yang melibatkan variabel. Jupri dkk. (2014) menjelaskan bahwa kurangnya kemampuan siswa dalam memahami suatu konsep matematis disebabkan karena kecendurang siswa tersebut yang mudah dalam melupakan suatu konsep. Dalam soal nomor 1 ini, jawaban siswa menunjukkan kemampuan siswa hanya pada pemahaman algoritma 
aljabar saja tanpa memahami konsep dari ekspresi aljabar itu sendiri. Lebih jelasnya yaitu jika siswa menyederhanakan 17-8x menjadi 9x (parsing obstacle) dan 2x +3 menjadi 5x (lack of closure obstacle).

\section{Penerjemahan Masalah Kontesktual ke Bentuk Aljabar}

Jupri dkk. (2014) menjelaskan bahwa miskonsepsi jenis ini disebut juga kesalahan konsep Mathematization (Menerjemahkan Masalah ke dalam Bentuk Matematis) baik secara horizontal maupun secara vertikal. Hasil penelitian menunjukkan bahwa peserta didik mengalami kesalahan konsep dalam menginterpretasikan masalah kontekstual aljabar ke dalam bentuk matematis aljabar itu sendiri. Hal itu ditunjukkan pada Tabel 1. soal nomor 4, Tabel 3., Tabel 4., dan Tabel 5.

Penerjemahan soal berbasis masalah kontekstual aljabar ke dalam bentuk matematis aljabar untuk didapat solusinya memang merupakan kegiatan yang cenderung sulit dilakukan oleh kebanyakan peserta didik. Hal tersebut dijelaskan juga oleh Herutomo (2017) bahwa kemampuan siswa dalam merepresentasikan suatu masalah ke dalam bentuk matematis masih di bawah rata-rata. Adapun Dreyfus (2002, dalam Herutomo, 2017) memaparkan terkait representasi yang dimaksud yaitu representasi simbolik, yakni secara eksternal melalui ucapan atau tulisan dengan tujuan untuk mengkomunikasikan konsep menjadi lebih mudah dipahami. Dari pernyataan tersebut, kegiatan representasi memang merupakan kegiatan yang penting dalam menyelesaikan soalsoal aplikasi karena jika kegiatan ini dilalui dengan kesalahan pemahaman konsepnya, maka hal tersebut tidak akan membantu dalam memecahkan suatu masalah kontekstual aljabar yang diberikan.

Wati dan Murtiyasa (2016) memaparkan beberapa penyebab dari miskonsepsi jenis ini yaitu karena rendahnya kemampuan siswa dalam berfikir kreatif terutama ketika dituntut untuk mengidentifikasi masalah ke dalam konsep matematis kemudian membuat strategi penyelesaiannya dengan mengaitkan informasi yang telah dimilikinya, kurang terbiasanya siswa dalam menghadapi soal-soal konteks nyata seperti soal PISA, siswa tidak terbiasa menggunakan proses pemecahan masalah dengan benar sesuai langkah Polya, siswa belum memahami konsep permisalan bentuk aljabar, serta kemampuan siswa yang rendah dalam memanipulasi masalah atau data ke dalam bentuk aljabar.

Penyebab terjadinya miskonsepsi siswa dalam menyelesaikan masalah kontekstual yaitu karena kesulitan siswa dalam memahami konsep matematisnya (Salsabila, Rahayu, Anastassia, Kharis, \& Putri, 2020). Kesulitan tersebut dialami karena frekuensi belajar siswa ataupun lingkungan belajar yang kurang kondusif. Pemahaman konsep matematis ini dibutuhkan adanya konsentrasi siswa secara maksimal agar tidak terjadi miskonsepsi. Ambarwati dkk. (2018) menjelaskan dalam penelitiannya bahwa soal PISA aljabar (Change and Relationship) perlu digunakan oleh guru dalam kegiatan pembelajaran secara berkala agar siswa tidak mengalami kesulitan dalam memahami suatu konsep matematis.

Terkait dominannya kesalahan konsep yang dialami peserta didik Indonesia dalam menyelesaikan masalah kontekstual aljabar, beberapa peneliti juga melakukan penelitian secara terpisah dalam rangka menemukan model pembelajaran apa yang dapat memperbaiki fenomena dengan indikator kemampuan siswa dalam pemahaman konsep matematis tersebut. Salah satunya yaitu penelitiaan yang dilakukan oleh Faqih (2019) yang menyatakan bahwa model pembelajaran kooperatif tipe TPS (Think-Pair-Share) dapat berpengaruh dalam meningkatkan kemampuan siswa SMP terhadap pemahaman suatu konsep matematis. Selain itu juga hasil penelitian dari Mawaddah dan Maryanti (2016) menunjukkan bahwa model pembelajaran penemuan (Discovery Learning) juga berdampak baik terhadap kemampuan pemahaman konsep matematis peserta didik SMP. Dalam menemukan solusi dari fenomena miskonsepsi aljabar kontekstual ini, pendidik beserta peneliti selanjutnya hendaknya dapat menganalisis berdasarkan bentuk-bentuk miskonsepsi aljabar yang telah dideskripsikan sebelumnya untuk menemukan model pembelajaran yang paling efektif dalam memperbaiki hasil belajar peserta didik dalam indikator kemampuan pemahaman konsep matematis. Dengan dilakukannya penelitian ini, maka diharapkan kepada para pendidik untuk dapat mengkaji bentuk-bentuk miskonsepsi aljabar kontekstual kemudian memperbaikinya dengan secara tepat menggunakan model pembelajaran berdasarkan kondisi siswa ketika pembelajaran berlangsung.

\section{CONCLUSIONS}

Beberapa hal yang dapat disimpulkan dari penelitian ini yaitu bahwasannya miskonsepsi peserta didik ketika menyelesaikan masalah kontekstual aljabar terjadi pada peserta didik dengan kemampuan matematis yang rendah dan sedang. Adapun klasifikasi empat bentuk miskonsepsi terkait masalah kontekstual aljabar, yakni miskonsepsi pada pemahaman operasi aritmatika aljabar (terjadi konjoining antara dua operator yang berbeda), miskonsepsi pada pemahaman makna dari variabel (masih dianggapnya variabel sebagai suatu konstanta, simbol, dan hanya representasi suatu nilai tertentu), miskonsepsi pada penyederhanaan ekspresi bentuk aljabar, dan miskonsepsi ketika menerjemahkan masalah kontekstual ke dalam bentuk matematis aljabar. Dari keempat bentuk miskonsepsi, penyebabnya karena terdapat beberapa kekeliruan yang dilakukan oleh pendidik (guru) terkait 
penggunaan model pembelajaran untuk materi aljabar yang dipelajari terutama ketika siswa baru saja mengenal materi aljabar di tingkat SMP tersebut. Dalam menanamkan konsep yang tepat, sekiranya guru harus dapat menyesuaikan model pembelajaran yang digunakan, misalnya dengan ditingkatkannya pemberian soal-soal aplikasi yang terkait dengan kehidupan sehari-hari ataupun soal-soal yang sifatnya open-ended.

\section{SUGGESTIONS}

Harapan pada penelitian selanjutnya adalah dapat ditemukannya solusi dari penerapan berbagai model pembelajaran inovatif yang sekiranya dapat memberikan pengaruh efektif terhadap indikator pemahaman konsep matematis, khususnya materi aljabar secara kontekstual. Selain itu, penelitian terkait analisis kesalahan dalam hal pemahaman konsep pada materi lainnya secara kontekstual juga dapat dilakukan untuk memperbaiki kesenjangan lain di bidang matematis.

\section{REFERENCES}

Aini, R. N., \& Siswono, T. Y. . (2014). Analisis pemahaman siswa SMP dalam menyelesaikan masalah aljabar pada PISA. MATHEdunesa, 3(2), 158-164.

Ambarwati, B., Hoerniasih, N., \& Abadi, A. P. (2018). Analisis kesalahan siswa dalam menyelesaikan masalah aljabar (change and relationship) PISA. Prosiding Seminar Nasional Matematika dan Pendidikan Matematika (Sesiomadika), 563-571.

Byrd, C. E., McNeil, N. M., Chesney, D. L., \& Matthews, P. G. (2015). A specific misconception of the equal sign acts as a barrier to children's learning of early algebra. Learning and Individual Differences, 38, 61-67. https://doi.org/10.1016/j.lindif.2015.01.001

Faqih, A. (2019). Model think pair share: apakah mempengaruhi pemahaman konsep matematika? JNPM Jurnal Nasional Pendidikan Matematika), 3(1), 40-50. https://doi.org/10.33603/jnpm.v3i1.1229

Herutomo, R. (2017). Miskonsepsi aljabar: konteks pembelajaran matematika pada siswa kelas VIII SMP. Journal of Basication: Jurnal Pendidikan Dasar, 1 (1), 1-8.

Herutomo, R. A., \& Saputro, T. E. M. (2014). Analisis kesalahan dan miskonsepsi siswa kelas VIII pada materi aljabar. Edusentris, Jurnal Ilmu Pendidikan dan Pengajaran, 1(2), 134-145.

Johar, R. (2012). Domain soal PISA untuk literasi matematika. Jurnal Peluang, 1(1), 30-41.

Jupri, A., Drijvers, P., \& van den Heuvel-Panhuizen, M. (2014). Difficulties in Initial Algebra Learning in Indonesia. Mathematics Education Research Journal, 26(4), 683-710. https://doi.org/10.1007/s13394-0130097-0

Lucariello, J., Tine, M. T., \& Ganley, C. M. (2014). A formative assessment of students' algebraic variable misconceptions. Journal of Mathematical Behavior, 33(1), 30-41. https://doi.org/10.1016/j.jmathb.2013.09.001

Mawaddah, S., \& Maryanti, R. (2016). Kemampuan pemahaman konsep matematis siswa SMP dalam pembelajaran menggunakan model penemuan terbimbing (discovery learning). EDU-MAT: Jurnal Pendidikan Matematika, 4(1), 76-85. https://doi.org/10.20527/edumat.v4i1.2292

Puspitarini, R. T. A. D., \& Masriyah. (2017). Analisis kesalahan siswa dalam menyelesaikan soal cerita pada materi aljabar. MATHEdunesa Jurnal Ilmiab Pendidikan Matematika, 2(6), 65-70. https://doi.org/10.1017/CBO9781107415324.004

Putri, A., Sumardani, D., Rahayu, W., \& Hajizah, M. N. (2020). Kemampuan Literasi Matematika Menggunakan Bar Model pada Materi Aljabar. AKSIOMA: Jurnal Program Studi Pendidikan Matematika, 9(2), 338-347.

Ramadhani, A. N., Yuwono, I., \& Muksar, M. (2016). Analisis kesalahan siswa kelas VIII SMP pada materi aljabar serta proses scaffolding-nya. Jurnal Silogisme: Kajian Ilmu Matematika dan Pembelajarannya, 1(1), 11-22. 
https://doi.org/10.24269/js.v1i1.243

Salsabila, E., Rahayu, W., Anastassia, S., Kharis, A., \& Putri, A. (2020). A Comparison between Generative Learning and Conventional Learning Model on Students' Mathematical Literacy in the 21st century. MSCEIS 2019. https://doi.org/10.4108/eai.12-10-2019.2296539

Salsabila, E., Rahayu, W., Kharis, S. A., \& Putri, A. (2019). Analysis of Mathematical Literacy on Students' Metacognition in Conic Section Material. Journal of Physics: Conference Series, 1417(1), 1-8. https://doi.org/10.1088/1742-6596/1417/1/012057

Silvia, S., Ratnaningsih, N., \& Martiani, A. (2019). Miskonsepsi kemampuan pemecahan masalah matematik berdasarkan langkah polya pada materi aljabar. Prosiding Seminar Nasional \& Call For Papers, 532-538.

Taqiyuddin, M., Sumiaty, E., \& Jupri, A. (2017). Miskonsepsi siswa sekolah menengah pertama pada topik pertidaksamaan linear satu variabel. Jurnal Pendidikan Matematika Indonesia, 1(1)(2013), 64-81.

Wati, E. H., \& Murtiyasa, B. (2016). Kesalahan siswa SMP dalam menyelesaikan soal matematika berbasis PISA pada konten change and relationship. Konferensi Nasional Penelitian Matematika dan Pembelajarannya (KNPMP I), 199-209. Surakarta: Universitas Muhammadiyah Surakarta.

Wildani, J. (2016). Analisis kesalahan siswa dalam menyelesaikan masalah aljabar. Unisda Journal of Mathematics and Computer Science, 4 (1), 9-18.

Yusrina, S. L., \& Masriyah. (2019). Profil berpikir aljabar siswa SMP dalam memecahkan masalah matematika kontekstual ditinjau dari kemampuan matematika. Jurnal Ilmiah Pendidikan Matematika, 8 (3), 472-479.

Zain, M., Idris, M., \& Rizal, M. (2016). Analisis pemecahan masalah aljabar siswa kelas VIII SMP Negeri 3 Palu. Jurnal Elektronik. Pendidikan Matematika Tadulako, 03(03), 358-372. 